\title{
Inhibitory Action on Aldose Reductase by Soybean Flavonoids
}

\author{
Tânia Toledo de Oliveira ${ }^{a}$, Tanus Jorge Nagem ${ }^{b}$, Luiz Carlos Guedes de \\ Miranda $^{a}$, Vanderlúcia Fonseca de Paula ${ }^{c}$, and Marco Antônio Teixeira ${ }^{d}$ \\ ${ }^{a}$ Departamento de Bioquímica e Biologia Molecular, Universidade Federal de Viçosa, \\ Av PH Rolphs s/n 36571-000 Viçosa - MG, Brazil \\ ${ }^{b}$ Departamento de Química, Universidade Federal de Ouro Preto, Campus Morro do \\ Cruzeiro, 35400-000 Ouro Preto - MG, Brazil \\ ${ }^{c}$ Departamento de Química,Universidade Federal de Viçosa, Av. PH Rolphs s/n \\ 36571-000 Viçosa - MG, Brazil \\ ${ }^{d}$ Departamento de Química da Universidade Federal de Minas Gerais, Pampulha, \\ Cidade Universitária, 30 270-010 Belo Horizonte - MG, Brazil
}

Received: April 28, 1995

Os flavonóides kaempherol, genisteína, naringenina, quercetina, morina, rutina, e quercitrina isolados do cultivar de soja UFV-5' foram testados como inibidores de aldose redutase. Os melhores resultados foram obtidos usando morina e quercitrina.

The flavonoids kaempherol, genistein, naringenin, quercetin, morin, rutin and quercitrin isolated from UFV-5' soybean's cultivars were tested as inhibitors of aldose reductase. The best results were obtained by using morin and quercitrin.

Keywords: flavonoids, soybean, aldose reductase

\section{Introduction}

Flavonoids that are present in higher plants, mainly leguminous, have aroused interest because of their inhibitory action on aldose reductase ${ }^{1,2,3}$. Aldose reductase catalyses the reduction of glucose and galactose, producing sorbitol and dulcitol respectively, using NADH as a co-factor ${ }^{4}$. This enzyme has been found in many animal tissues, such as the retina, blood, the cornea, the sciatic nerve, the liver, kidneys and sperm.

The excessive presence of sorbitol in diabetic rats and humans causes the formation of cataracts ${ }^{2,5,6}$. A similar result was also observed by the presence of dulcitol in the lenses of rats maintained on a diet rich in galactose ${ }^{7}$. In the lenses of diabetic rats the content of sorbitol may be as high as $50 \mu \mathrm{mol} / \mathrm{g}$, while in the lenses of galactosemic rats, the level of dulcitol can rise to approximately $80 \mu \mathrm{mol} / \mathrm{g}$ wet weight tissue ${ }^{4}$. It has been demonstrated that cataract for- mation ceases under the systemic administration of aldose reductase inhibitors ${ }^{7,8}$. In order to solve this problem several compounds have been tested ${ }^{6,8,9,10}$, besides flavonoids $^{1,3}$. The purpose of the present study is to isolate, purify and identify flavonoidic compounds of the UFV-5, soybean's cultivar, as well as to test their inhibitory action in aldose reductase in vitro.

\section{Material and Methods}

The flavonoids kaempherol (I), genistein (II), quercetin (III), naringenin (IV), morin (V), rutin (VI) and quercitrin (VIII) were extracted from the UFV-5' soybean's cultivar, following Hardin's technique ${ }^{11}$. The sample was heated in a bath-water with acetic acid for $10 \mathrm{~min}$, and then filtered. The filtrate was treated with $\mathrm{HCl} 1 \mathrm{~N}$ for one hour, and then extracted with anhydrous ethyl ether which was evaporated giving a residue containing flavonoidic components isolated by chromatography. 
Identification of the flavonoids was made by UV, NMR and IR spectroscopy techniques and comparison with authentic samples available in our laboratory. The verification of the inhibitory action of aldose reductase involved Shimizu's technique ${ }^{1}$ at room temperature, by using a phosphate buffer solution $(0.01 \mathrm{M} ; \mathrm{pH} 6.2 ; 0.014 \mathrm{mM}$ of NADPH, $10 \mathrm{mM}$ of glucose or galactose and $25 \mu \mathrm{L}$ of aldose reductase with the addition of $\mathrm{H}_{2} \mathrm{O}$ to a volume of $1.5 \mathrm{~mL}$ ). The control test contained all the compounds, excepting the glucose or galactose.

The reaction was initiated by the addition of aldose reductase, and the rate of oxidation from NADPH to NADP was observed by the decrease in the absorbancy at $340 \mathrm{~nm}^{1}$.

The flavonoids were prepared in concentrations of $10^{-4}$ $\mathrm{M}, 10^{-5} \mathrm{M}, 10^{-6} \mathrm{M}$, and $10^{-7} \mathrm{M}$ and were dissolved in water with the addition of $\mathrm{NaOH}$, the $\mathrm{pH}$ was adjusted to 7.0 and then added to the test mixture.

\section{Results and Discussion}

The inhibitory action of flavonoids on aldose reductase (D-mannitol-1- phosphate-dehydrogenase of E. coli) in different concentrations of flavonoids (Table 1), demonstrates that a concentration of $10^{-4} \mathrm{M}$ is the best promoter of the inhibitory action of the enzyme. On the other hand, it also confirms that the flavonoids morin and quercitrin presented higher inhibitory action relative to the enzyme. Data on the Table 4 shows that at the same concentration of $10^{-5}$ $\mathrm{M}$, the best results were obtained from the flavonoids rutin, quercitrin, and naringenin. These results are in agreement with those obtained by Varma ${ }^{12}$ for quercitrin, acetate of 2-quercitril and quercetin.

It is known that enzymes as aldose reductase reacts with substrate as glucose or galactose with the formation of a complexe. According to these results it can be seen the most preference of the enzyme for reacting with flavonoids

Table 1. Inhibitory effect of flavonoids at different concentrations on aldose reductase.

\begin{tabular}{llllr}
\hline Compounds & \multicolumn{4}{c}{ Concentrations } \\
\hline & $10^{-4} \mathrm{M}$ & $10^{-5} \mathrm{M}$ & $10^{-6} \mathrm{M}$ & $10^{-7} \mathrm{M}$ \\
\hline Kaempherol & $80.33^{\mathrm{D}} * \#$ & $60.33^{\mathrm{D}}$ & $40.33^{\mathrm{E}}$ & $7.00^{\mathrm{C}}$ \\
Genistein & $48.66^{\mathrm{F}}$ & $28.66^{\mathrm{E}}$ & $18.66^{\mathrm{F}}$ & $0.00^{\mathrm{D}}$ \\
Quercetin & $83.66^{\mathrm{C}}$ & $63.66^{\mathrm{C}}$ & $44.33^{\mathrm{D}}$ & $30.66^{\mathrm{A}}$ \\
Naringenin & $75.66^{\mathrm{E}}$ & $74.66^{\mathrm{A}}$ & $54.66^{\mathrm{A}}$ & $21.66^{\mathrm{B}}$ \\
Morin & $96.66^{\mathrm{A}}$ & $67.66^{\mathrm{B}}$ & $47.66^{\mathrm{C}}$ & $0.00^{\mathrm{D}}$ \\
Rutin & $91.66^{\mathrm{A}}$ & $71.66^{\mathrm{A}}$ & $51.66^{\mathrm{AB}}$ & $0.00^{\mathrm{D}}$ \\
Quercitrin & $97.66^{\mathrm{A}}$ & $71.66^{\mathrm{A}}$ & $51.66^{\mathrm{A}}$ & $20.66^{\mathrm{AB}}$ \\
\hline
\end{tabular}

* The values followed by at least one equal letter do not differ statistically by Tukey's Test (5\% probability level).

\#-Average values of $\%$ inhibition of flavonoids on aldose reductase.
Table 2. Analysis of Variance ${ }^{13}$.

\begin{tabular}{lcc}
\hline & free grade & mean square \\
Flavonoid & 6 & $1777.43^{*}$ \\
Concentration & 3 & $18966.14^{*}$ \\
Flav x Concentration & 18 & $251.87^{*}$ \\
Residue & 56 & 1.6093 \\
\hline
\end{tabular}

*Significant at level of $5 \%$ of probability.

containing sugar unit in its structure. The highest porcentage of inhibition obtained for quercitrin $97,66 \%$ is in agreement with that possibility.

From the analysis of variance (Table 2) a significant interaction between flavonoids and concentration can be seen.

\section{Conclusions}

From the UFV-5' cultivar of Glycine max (soya) it was possible to isolate and identify the flavonoids kaempherol, genistein, quercetin, naringenin, morin, rutin and quercitrin. The identification was achieved by UV, IV and NMR spectroscopic studies. At a concentration of $10^{-4} \mathrm{M}$, the flavonoids morin and quercitrin were those which demonstrated higher inhibitory action. On the other hand, at a concentration of $10^{-5} \mathrm{M}$, the best results were achieved by the flavonoids naringenin, rutin, and quercetrin.

These results showed the great possibility to use, in the future, the soybean as prevention of cataract in foods or by using these compounds associated to the medicines, in order to avoid the cataract formation.

\section{References}

1. Shimizu, M.; Terashima, I.S.; Hayashi, T.; Arisawa, M.; Morita, N.; Kurokawa, S.K.K.; Ito; Hashimoto, Y. Phytochemistry 1984, 9, 1885.

2. Varma, S.D.; Kinoschita, J.H. Biochem. Pharmacol. 1976, 25, 2505.

3. Chaudry, P.S.; Cabrera, J.; Juliani, H.R.; Varma, S.D. Biochem. Pharmacol. 1983, 32, 1995.

4. Kinoschita, J.H. Invest. Ophtalmol \& Vis Sci. 1965, $4,786$.

5. Heyningen, R.Van. Nature 1959, 184, 194.

6. Lerner, B.C.; Varma, S.D.; Richards, R.D. Arch. Ophthalmol. 1984, 102, 917.

7. Varma, S.D.; Kinoschita, J.H. Documenta Ophtalmol. 1976, 8, 305.

8. Dvornick, D.; Simard-Duquesne, N.; Krami, M.; Sestanj, K.; Gabbay, K.H.; Kinoschita, J.H.; Varma, S.D.; Merola, L.O. Science 1973, 182, 1146.

9. Varma, S.D.; Shocket, S.S.; Richards, R.D. Invest. Ophtalmol. \& Vis. Sci. 1979, 18, 237. 
10. Varma, S.D.; El-Aguizy, H.K.; Richards, R.D. Acta Ophthalmol. 1980, 58, 748.

11. Hardin, J.M.; Stutte, C.A. Anal. Biochem. 1980, 102, 171.
12.Varma, S.D. Pharmacol. Struct. Activ. Relat.1986, 1, 343.

13. Gomes, F.P. In Curso de Estatística Experimental. 6a Ed. Piracicaba, Livraria Nobel, 1976, p 430. 